\title{
Determinants of Trade Credit Extended by Manufacturing Firms Listed in Pakistan
}

\begin{abstract}
Nisar Ahmad', Talat Afzaㄹ, Bilal Nafees ${ }^{3}$
Abstract

This paper investigates the determinants of trade credit extended by listed manufacturing firms in Pakistan. Dynamic panel model is estimated by applying system GMM one step and two step estimators on the financial data of 327 manufacturing firms listed in PSX Pakistan for the period 2005 to 2015. Results of the study reveal that trade credit policies of firms are dynamic instead of static. Firms have the target level for trade credit extended and make partial adjustment over time to reach at its optimal level. However, the speed of making adjustments is relatively low due to high cost of making adjustments. Positive and significant relationship of trade credit extended with credit received from suppliers and banks indicates that listed manufacturing firms are following the credit redistribution hypothesis. Further, it is also observed that sales growth and market power of firms have significant and negative effect whereas inventory and relative liquidity position have significant and positive effect on the trade credit extended by listed manufacturing firms. Overall findings of the study suggest that managers should consider changes in the financial characteristics of their firms while making partial adjustments in the trade credit policy. For future research, investigation of the effects of customers' characteristics and financial development on the trade credit extended by listed manufacturing firms is proposed.
\end{abstract}

JEL Classification: C33; G39

Keywords: Dynamic Panel Model, Listed Manufacturing Firms, and Trade Credit Extended.

\section{Introduction}

Trade credit is an important constituent of corporate finance (Rajan \& Zingales,

1 Assistant Professor, Hailey College of Commerce, University of the Punjab Lahore, Pakistan. Email: nisar@hcc.edu.pk

2 Professor, The Government Sadiq College Woman University, Bahawalpur, Pakistan. Email: svc@ gscwu.edu.pk

3 Lecturer, University of Education, Lower Mall Campus, Lahore, Pakistan. Email: bilalnafees@ hotmail.com

\begin{tabular}{lll} 
ARTICLE HISTORY & \\
\hline 15 Jun, 2017 Submission Received & 3 Aug, 2017 & First Review \\
\hline 26 Aug, 2017 Revised Version Received & 9 Sep, 2017 & Second Review \\
\hline 18 Sep, 2017 Revised Version Received & 5 Oct, 2017 & Accepted
\end{tabular}


1995). Jain (2001) argued that nonfinancial firms extend credit to their customers and work as intermediaries between banks and the ultimate buyers. It is largely provided by firms to their customers and represents a high percentage of the firm's total assets. Sometimes it is accounted for more than $25 \%$ of total assets of firms (Mateut, Bougheas \& Mizen, 2006).

Meltzer (1960) found that firms extend trade credit to their financially constrained customers in accordance with credit redistribution hypothesis. Trade credit once extended by firms to their customers; later it will become a matter of their policy (Nilsen, 2002). Due to extensive use of trade credit by manufacturing firms, it has been an important and interesting area for research in the field of corporate finance since long. In existing literature, most of the previous studies investigated the motives and determinants of trade credit practices in the context of developed countries e.g. Petersen and Rajan (1994; 1997) in USA; Wilson and Summer (2002); later Garcia-Teruel and Marteniz-Solano (2010) in UK; Tsuruta (2013) in Japan; and Desai, Foley and Hines (2016) in USA. Huyghebraet (2006), Garcia-Teruel and Marteniz-Solano (2010b) focused on Europe, while Delannay and Weill (2004) investigated the determinants of trade credit in transition countries.

However, little effort is made to explain the determinants of trade credit in developing countries, where financial markets are less developed and financial institutions are fewer. In these countries, listed manufacturing firms extend credit to their customers and mitigate the deficient role of financial intermediaries. Some previous studies tested the motives and determinants of trade credit in the context of developing countries. For example Vaidya (2011) in India; Zhang (2011) in Thailand; Guy \& Mazra (2012) in Camroon. With reference to financial development, Pakistan is ranked among ten least financially developed countries (World Economic Forum, 2012) $)^{4}$. Moreover, trade credit supplied by listed manufacturing firms in Pakistan has grown on average by $11.47 \%$ during 2010 to 2015 (State Bank of Pakistan, 2015) ${ }^{5}$. In spite of the important role of trade credit, and its advantages over bank credit, only one study on trade credit conducted by Khan, Tagar and Bhutto (2012), was found in existing literature. This study focused on the determinants of trade credit extended by textile firms listed on KSE Pakistan, whereas trade credit is being extended by all listed manufacturing firms. Therefore, we have extended the investigation by considering all manufacturing sectors in Pakistan. The present study is aimed to contribute to existing literature on trade credit in following stances.

4 Financial development report. USA Inc. New York, USA. Retrieved from http://www3.weforum. org/docs/WEF_FinancialDevelopmentReport_2012.pdf

5 Sources $\mathcal{E}$ uses of funds non-financial private corporate sector in Pakistan. Flow of Funds Division Statistics $\mathcal{E}$ DWH Department State Bank of Pakistan. Retrieved from http://www.sbp.org.pk/departments/stats/Funds_Flow/Sources/2014-15.pdf 
First, Pakistan is a developing economy characterized with less developed financial system where credit redistribution by listed firms is a common business practice. This study has focused to provide empirical evidence on credit redistribution behavior of firms. Second, trade credit decisions like capital structure, dividend policy, cash management and investment decisions etc. are dynamic instead of static (Flannerya \& Hankins, 2013). Most of the previous studies (see for example Chou, Yang \& Line, 2011; Khan et al., 2012; Coulibaly, Sapriza \& Zlate, 2013; Desai et al., 2016.) focused on static behavior of trade credit. This study is designed to increase the understanding about dynamic trade credit behavior of firms. Third, firms extend and receive trade credit simultaneously (Gibilaro \& Mattarocci, 2011). It implies that trade credit received and trade credit extended are complement of each other. Existence of simultaneity between trade credit extended and trade credit received gives rise to endogeneity (Kwenda \& Holden, 2014; Murfin \& Njoroge, 2015) that is a common problem in corporate finance research (Roberts $\&$ Whited, 2013). This study applies system GMM estimator with one-step and two-step to control the endogeneity problem.

Rest of the paper is organized as follows: Hypotheses are stated in in next section. Data sources, variables and empirical model are explained in section 3. Results of analysis are discussed in section 4 . Section 5 concludes the study.

\section{Literature Review and Hypotheses}

\subsection{Theories of trade credit}

Scholars put forward a number of theories to explain the motives of firms for supplying and receiving trade credit. These theories are briefly discussed to provide theoretical understanding of trade credit extended by firms to their customers.

According to financing theory trade credit is viewed as a substitute of formal credit due to inefficiency of financial markets. Market frictions and imperfections give rise to credit rationing. Resultantly, credit constrained firms are left with no choice except to use trade credit as a substitute of bank credit and market credit (Petersen \& Rajan, 1997). Financial Advantage Theory established suppliers readily provide credit to their customers due to their comparative advantage over banks regarding liquidating cost, transaction cost and information symmetry (Biais \& Gollier, 1997; Jain, 2001).

Liquidity Theory holds that liquidity constrained firms' use more trade credit while firms holding good liquidity position extend more trade credit to their financially constrained firms (Emery, 1984). In less developed financial markets, large sized and creditworthy firms act as financial intermediaries and redistribute short term funds through trade credit to their financially weak customers and provide them liquidity 
(Deloof \& Van Overfelt, 2011).

Market power theory justifies that firms with high brand equity need less to extend trade credit but demand more trade credit. Moreover, due to market power of larger firms, their suppliers readily provide them trade credit. But this theory does not explain the trade credit extended and used by small firms having no brand equity. Financial distress theory (based on the opportunistic behavior of buyers and sellers) explains that when a supplier is in financial distress and cannot credibly threat to stop supplies then buyers taking advantage of suppliers' distress delayed payment. Particularly when the buyer is one of the principal customers or when suppliers are small and sell to many customers. Supplier opportunistic behavior exist when he has monopoly power and extend credit on relaxed terms to keep buyer dependent on him. Majority of firms are in good financial position but even though these firms widely receive and extend trade credit. This theory does not cover the trade credit practices of financially sound firms.

Quality guarantee theory presented by Smith (1987) based on asymmetry of information about the quality of product between buyer and seller. This theory is also called asymmetric information theory and justifies that seller offers trade credit to signal the quality of product. When customer is not aware about the quality of the product their suppliers provide them opportunity to check the quality of product during credit period. Mostly, new firms or the firms offering new product sell on credit and allow their customers to make payment after using the product. This theory does not explain the trade credit behavior of firms having good reputation and well established market for their product.

Agency theory (Jensen \& Meckling, 1976) of trade credit is based on the argument that relationship between seller and buyer is of principal and agent. Ex-anti information asymmetry about the characteristics of product between seller and buyer give rise to adverse selection while ex-post information asymmetry about buyer paying behavior gives rise to moral hazards. In order to reduce the ex-anti information asymmetry firms offer trade credit to their clients and to reduce ex-post information asymmetry, firms offer cash discount term along with credit term i.e. two part credit terms. But this theory provides no explanation of the trade credit extended by firms to their associates where adverse selection and moral hazard problem are less likely to occur.

Transaction cost theory (Schwartz, 1974) rationalizes the use of trade credit as an operational tool. According to this theory, firms extend and receive trade credit to reduce their transaction cost particularly when the frequency of transactions between a particular buyer and seller is high and cost of each transaction is very high. This theory provides no explanation of the trade credit extended by firms particularly in 
the markets of capital goods where transaction frequency with individual customers is low. In 1988 Brennan, Maksimovic and Zechner, introduced the Price discrimination theory. This theory gives explanation based on the assumption that trade credit is used by firms as a non-price competition strategy to differentiate their product in a highly competitive market. Firms extend trade credit to their customers as a marketing tool like advertising to differentiate their product in competition. Why firms in monopolistic structure of market extend or supply trade credit to their customers is not explained by this theory.

Tax theory (Brick \& Fung, 1984) emphasizes that firm compare the after tax cost of alternative sources of finance before availing credit from any source. Trade credit is not free of cost. Firms compare the implicit cost of trade credit with the after tax explicit cost of borrowing from other sources. Incase buyers and seller are taxed differently, then firms charged higher income tax have less after tax cost of borrowing and are likely to offer trade credit or vice versa. But, why firms with lower cost of borrowing, use trade credit is not answered by this theory. Moreover, this theory does not provide any explanation about the trade credit extended by firms paying higher cost of borrowing.

Signaling theory presented by Biais and Gollier in 1997, emphasizes that small and opaque firms use trade credit to signal about their creditworthiness in less developed financial market. Suppliers of bank credit and market credit use trade credit as a source of private information of trade credit suppliers to assess the creditability of borrowers. This theory does not explain the use of trade credit by larger and listed firms who are substantially transparent and demonstrate good credit rating.

Credit Relationship Theory. According to this theory firms extend trade credit to maintain their credit relationship with customers (Bastos, 2010) and make partial adjustments in their credit policy over time in the light of their past credit experience with customers (Blasio, 2005).

Above mentioned theories are explaining the one or the other reason for extending trade credit by firms. Numerous empirical studies have been documented to test the relevance of these theories but these studies focused differently. As these theories are providing partial explanation of trade credit, so, it is premature to decide which theories are now lacking implication and which one has universal acceptability. Furthermore, it may possible that trade credit extended by firms is supported by more than one theory. Pakistan is a characterized with less developed financial system, where listed manufacturing firms having access to bank credit, market credit. Furthermore, these firms are likely to receive more credit from their suppliers due to their market power. Therefore, these firms are expected to play the role of financial 
intermediaries and transfer liquidity to their credit rationed customers. In order to examine the determinants of trade credit extended by listed manufacturing firms and to test the credit relationship, credit redistribution, price discrimination, financial distress, liquidity, transaction cost theories, we developed the following hypotheses.

\subsection{Hypotheses development}

\subsubsection{Trade credit extended in previous period}

Trade credit extended by firms to their customers in current period may be affected by the trade credit extended in the previous period (Bastos, 2010). It implies that firms, which supplied more credit to their customers in the previous year, are expected to supply more trade credit in current year. It also suggests that firms extend trade credit to maintain their business relationship with the customers. Furthermore, stability of credit policy and trade credit contracts of firms with their customers, justify that firms' current trade credit practices are influenced by their previous trade credit practices (Blasio, 2005). Gibilaro and Mattarocci (2011) found that trade credit supplied by firms in the current year is positively related to trade credit supplied in the last year. Thus, following relationship is expected between trade credit extended in current year and trade credit extended in the previous period.

$\mathrm{H}_{\mathrm{a} 1}$ : Trade credit extended in the previous period has significant effect on the trade credit extended in the current period.

\subsubsection{Trade credit received}

Trade credit being a short term financing source is simultaneously demanded and extended by firms (Burkart \& Ellingsen, 2004). It implies that trade credit extended and received by firms are influenced by each other (Kiyotaki \& Moore, 1997). Firms getting late payments from their customers are likely to delay payments to their suppliers (McMillan \& Woodruff, 2002). This shows that credit collection behaviour of firms is influenced by their credit payment behaviour. Firms might use trade credit to finance their trade receivables. Murfin and Njoroge (2015) revealed significant positive relationship between supplier's receivable investment policy and buyer's payable policy. According to matching theory of financing, firms match the maturity of assets with maturities of liabilities. Thus, firms supplying credit to their customers for longer period are expected to demand more credit from their suppliers for longer period. Firms match the maturity of their trade receivables and trade payables (Diamond, 1991; Bastos, 2010; Yang, 2011; Kwenda \& Holden, 2014). Gibilaro and Mattarocci (2011) revealed that causality condition exists between trade credit provided by firms to their customers and trade debt received by firms from their suppliers. Furthermore, Credit redistribution hypothesis emphasizes that firms receiving more credit from 
their supplier are likely to supply more credit to their customers. On the basis of said theoretical arguments and empirical findings, following hypothesis is stated.

$\mathrm{H}_{a 2}:$ Trade credit used by listed manufacturing firms is positively related to trade credit extended by them.

\subsubsection{Availability of short term bank credit}

Trade credit extended by firms is likely to be influenced by the availability of short-term bank credit or by their access to short-term bank credit. Schwartz (1974) pointed out that if banks are the main supplier of credit, then firms having greater ability to raise funds from financial intermediaries can transfer credit to their financially constrained customers through trade credit. Petersen and Rajan (1997) found that firms having sufficient access to short-term bank credit supply more trade credit to their credit rationed customers. Bougheas, Mateut, and Mizen (2009) observed that bank credit is the complement of trade credit extended by firms. It implies that firms use short-term bank credit to finance trade credit. Therefore, following hypothesis is proposed about the relationship between short term bank credit and trade credit

$\mathrm{H}_{a 3}$ : Access to short-term bank credit received is positively related to trade credit extended.

\subsubsection{Market power}

Aaccording to Omiccioli (2005) trade credit practices of firms are significantly influenced by the features of economic sector and by their characteristics particularly their market power (Mian \& Smith, 1992; Wilson \& Summers, 2002). Firms with higher market power can pursue price discrimination motive by extending trade credit to their customers. Thus, firms with ability to charge higher markup have the incentive to generate additional cash flows by selling extra units on credit to their customers. Generally, leading firms in the industry pursue price discrimination motive by offering two part credit terms (Brennan et al., 1988; Mian \& Smith, 1992). The implicit cost of trade credit is high in case discount term is offered by suppliers. Creditworthy customers make payment within discount term and avoid the cost of making delayed payments. While for low credit rating firms it may be a cheaper source of financing than borrowing from financial institutions (Brennan et al., 1988; Petersen \& Rajan, 1997). Khan et al. (2012) reported negative relationship between market power of a firm and trade credit extended while positive relationship between trade credit extended and market power of a firm was observed by Niskanen, and Niskanen, (2006). On the basis of above said argument, we expect a negative relationship between trade credit extended by firms and their market power.

$\mathrm{H}_{a 4}$ : Market power of a firm is negatively related to trade credit extended by it. 


\subsubsection{Sales growth}

Firms use trade credit policies to pursue their growth targets (Delannay \& Weil, 2004), and it is used as an important determinant of trade credit extended by firms. Meltzer (1960) pointed out that instead of direct reduction in pricef, larger firms extend trade credit to their customers to stimulate demand of their product in the periods of constrained monetary policy. Emery (1987) found that suppliers facing decline in demand of their product allow trade credit to their financially constrained customers instead of accumulating costly inventory for sale in future. To follow commercial motive, firms may use trade credit policies as a competitive tool to increase their sales. High growth rate is positively valued by suppliers and banks as it is an indicator of firm's good health (Niskanen, \& Niskanen, 2006). Growing firms need funds to finance their own growth and resultantly extend less credit to their customers (Deloof \& Rocca, 2012). But firms with negative growth rate might extend credit to increase their depressed sales (Ge \& Qiu, 2007). Moreover, clients taking advantage of their suppliers' financial fragility may delay payments. Thus, we expect negative relationship between sales growth and credit extended by firms. by firms.

$\mathrm{H}_{25}:$ There is negative relationship between sales growth and trade credit extended

\subsubsection{Cash flows from operations}

According to financing motive, firm with high profitability are generating more cash flows and thus transfer liquidity to their customer by selling goods on credit. From a theoretical perspective, firms having capacity to generate cash flows would make extra sales by extending trade credit. Since, firms with a good ability to generate cash flows extend more trade credit (Grave, 2011). On the contrary, firms facing losses may offer more credit to their customers to reduce their losses from business operations whereas firms earning higher operating profit need less to extend trade credit. Moreover, allowing delayed payments to customers reduces the cash flows from operations. Therefore, we expect that the relationship between cash flows from operations and trade credit extended is negative.

$\mathrm{H}_{a 6}$ : Cash flows generated by a firm from operations are negatively related to trade credit extended by it.

\subsubsection{Firm's size}

Trade credit practiced by firms is sensitive to firm's size (Fazel, 1997). Size of a firm can affect the trade credit extended in two different dimensions. On the one hand, larger firms have more bargaining power and are less likely to hold large amount 
of costly accounts receivables. Wilson and Summers (2002) found that trade credit behavior of firms is influenced by their size and reputation. Longer net credit term is offered by suppliers when they are facing the problem of reputation. Two part credit term is offered by firms when they are afraid from opportunistic behavior of customers and want to reduce cash flows problem. On the other hand, financial motive induced the larger firms with easy access to bank credit to assist their financially constrained customers by extending trade credit. Khan et al. (2012) found that trade credit extended by textile firms, is significantly affected by the size of firms. Furthermore, studies conducted by, Chou et al. (2011), Deloof and Rocca (2012) and Desai et al. (2016) showed that firms' creditworthiness is positively associated with trade credit extended by them. As mixed arguments are found in literature, thus we expect the following relationship between firm's size and trade credit extended by it.

$\mathrm{H}_{\mathrm{a} 7}$ : There is significant relationship between firms' size and trade credit extended.

\subsubsection{Stocks-in-trade}

To pursue operational motive of inventory management, firms with more inventory holding cost extend more credit to reduce holding cost of inventory. Both accounts receivable and inventory are substitute from the view point of assets management. Emery (1987) emphasized that firms avoid accumulating costly inventory and make trade-off between the cost of holding stock-in-trade and the benefit of allowing trade credit to their customers. Petersen and Rajan (1997); Bougheas et al. (2009) and Vaidya (2011) estimated a significant negative relationship of stocks' level with trade credit extended by firms. They argued that when production exceeds sales it causes piling-up of costly stocks. Thus, firms are left with no choice except to offer trade credit for increasing the turnover which results decrease in the level of stocks. Alternatively, trade credit and stock-in-trade are complements of each other. According to complementary hypothesis of current assets, both trade credit extended and inventory are complements of each other. It is generally observed that manufacturing holding larger inventory have larger investment in receivables than the firms with smaller inventory. Hence, we establish the following hypothesis:

$\mathrm{H}_{a}:$ There is significant relationship between stock-in-trade held by a firm and trade credit extended by it.

\subsubsection{Relative liquidity position}

Relative liquidity measures the short term liquidity risk of the firm. Higher the value of relative liquidity lower is the liquidity risk. Firms with lower liquidity risk are likely to offer more trade credit to their customers. Vaidya, (2011), and Chou et al. (2011) found positive relationship between relative liquidity position and trade credit 
extended. While negative relationship between relative liquidity and trade credit was observed by Mateut, Mizen, and Ziane (2011), Grave, (2011). Tsuruta (2013) revealed that firms facing liquidity shortage reduce the supply of trade credit to their customers. Thus, positive relationship is expected between trade credit extended by firms and their relative liquidity position.

$\mathrm{H}_{a 9}$ : There is positive relationship between relative liquidity position of a firm and trade credit extended by it.

\section{Data and Methodology}

\subsection{Data sources and sample}

The focus of this empirical study is to estimate the impact of firms' financial characteristics on trade credit extended by listed manufacturing firms in Pakistan. For this purpose, data about financial characteristics of firms for the period 2005 to 2015 are obtained from Balance Sheet Analysis of non-financial firms published by statistical division of State Bank of Pakistan.

The choice of listed manufacturing firms is justified on the following grounds. First, large manufacturing sector is the recipient of major share of credit allocated by banks to private sector in Pakistan. Second, these firms are listed in stock exchange and have access to credit market. Third, these firms having access to market credit, bank credit and trade credit are in a better position to redistribute credit by extending trade credit to their credit rationed customers. Firms belonging to financial sector, services business, renting and other services are not considered due to the specific nature of their business activities (Niskanen \& Niskanen, 2006; Akinlo, 2012). The choice of time period covered by this study is influenced by significant developments in credit market and improvement in credit information sharing in Pakistan during 2005-2015. Hence, this study is confined to investigate the trade credit behavior of listed manufacturing firms during 2005-2015.

For choosing the appropriate sample of listed manufacturing firms, purposive sampling technique is used. Firms that are not supplying trade credit to their customers are not considered for the reason that the question under examination is not relevant to them. For further refining the sample, following filtering criteria are applied. At first step, manufacturing firms which were found listed in Pakistan Stock Exchange (PSX) were selected as a part of initial sample. From among the manufacturing firms listed on PSX, 386 firms were chosen on the basis of availability of their financial data for the study period (2005-2015).

At second step, like Guariglia and Mateut (2011) and Kwenda and Holden (2014) 
listed manufacturing firms which have zero sales or missing data of sales are dropped from the initial sample. At third step, consistent with Yang (2011) and Vaidya (2011) listed manufacturing with financial data for the period less than five consecutive years are dropped because firms takes some years in establishing trade credit relationship with their customers. The final sample size is equal to 84.7 percent of the total manufacturing firms listed in PSX and provides balanced panel data of 327 listed manufacturing firms over the time period of 11 years.

\subsection{Variables and their measurement}

Following variables are used in this study to study the relationship between financial characteristics of the firms and trade credit extended by them.

\subsubsection{Dependent variable}

Trade credit extended means delay in payment allowed by sellers to their customers. In line with Vaidya (2011) and Desai et al. (2016) accounts receivable to sales ratio is used in the study as a proxy for dependent variable i.e. Trade Credit Extended by manufacturing firms. Next is the description of determinants of trade credit extended by manufacturing firms.

\subsubsection{Independent variables}

With reference to findings of previous empirical studies and question under investigation, following independent variables are selected for the current study. These variables include: first lag of trade credit extended, trade credit received, availability of short term bank credit, gross profit, sales growth, and cash flows from operations, size of firms, inventory level and relative liquidity position. Measurements of these variables are presented in Table 1.

\subsection{Model specification for trade credit extended by listed manufacturing firms}

Generally, firms have the target level for trade credit and make partial adjustments over time to reach at its optimal (target) level. Target level of trade credit extended is modelled as follows.

$$
T C E^{*}{ }_{i t}=\delta_{0}+\sum_{j=1}^{N} \delta_{j} X_{j i t}+\varepsilon_{i t}
$$

In Equation 1, firms are indicated by subscript $i$ that varies from 1 to $\mathrm{N}$ and years are represented by subscript $t$ that varies from 1 to $T$. $T C E^{*}$ it is the target level of trade credit extended by firm $i$ during time period $t . \delta_{0}$ is intercept term and $\mathrm{X}_{\mathrm{j}, \mathrm{it}}$ is (jx1) vector of firm specific determinants of trade credit extended by firms and $\delta_{\mathrm{j}}$ 


\begin{tabular}{|c|c|c|c|c|c|c|c|c|c|c|}
\hline 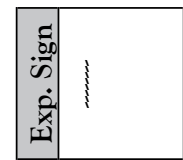 & & & & + & $\stackrel{+}{+}$ & $\stackrel{1}{+}$ & \pm & $\stackrel{+}{+}$ & \pm & $\stackrel{+}{+}$ \\
\hline 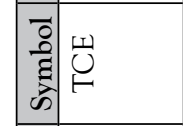 & 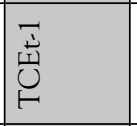 & $\underset{f}{\stackrel{x}{U}}$ & & $\begin{array}{l}\text { U } \\
\text { की }\end{array}$ & 0ิ & O & 足 & $\stackrel{N}{\omega}$ & 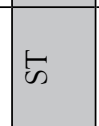 & $\stackrel{a}{g}$ \\
\hline 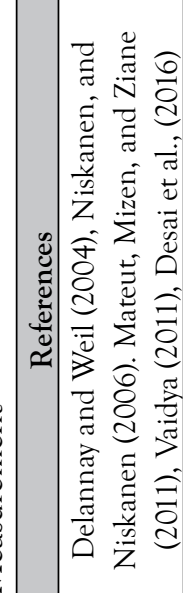 & 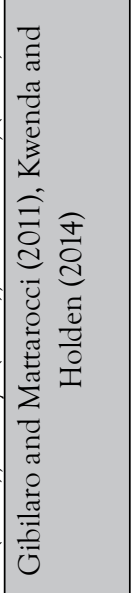 & 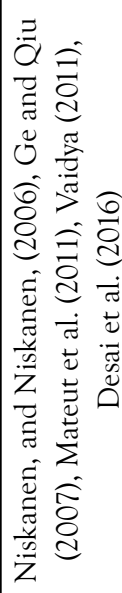 & & 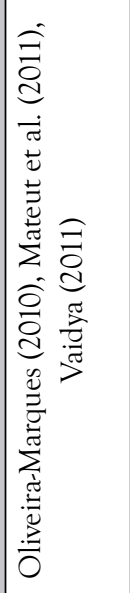 & 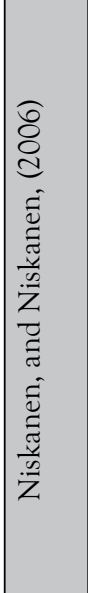 & 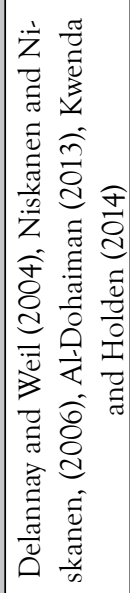 & 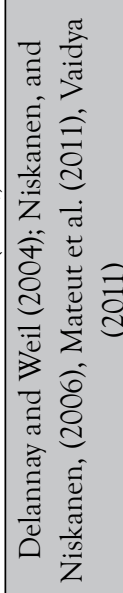 & 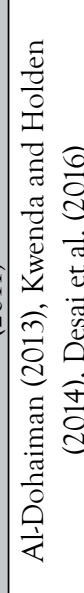 & 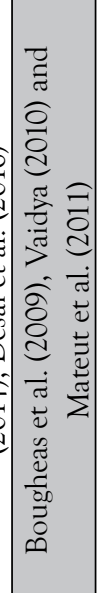 & 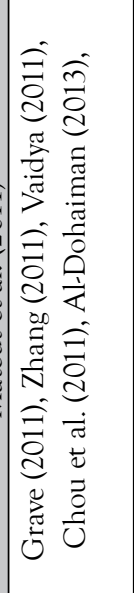 \\
\hline 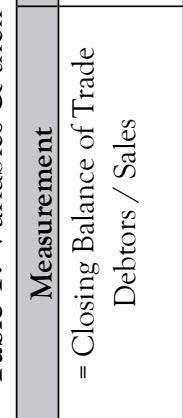 & 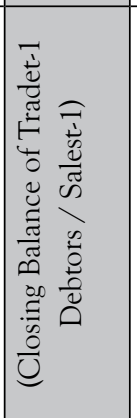 & 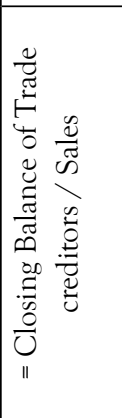 & & 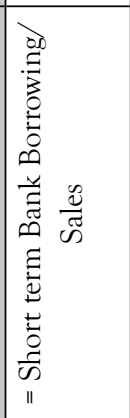 & 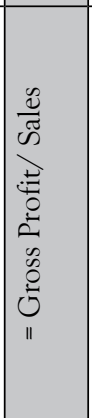 & 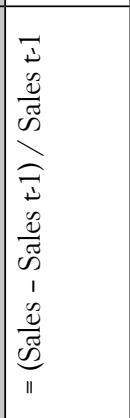 & 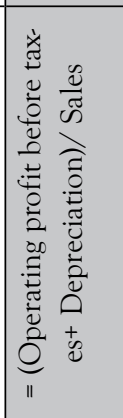 & 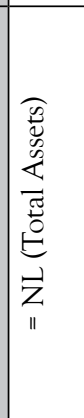 & 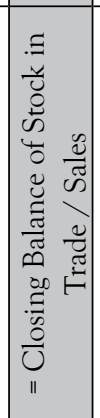 & 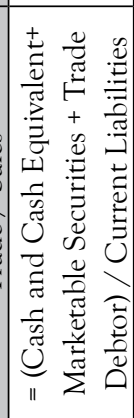 \\
\hline 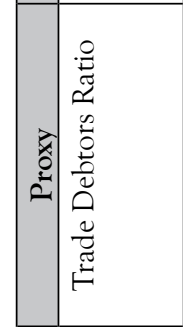 & 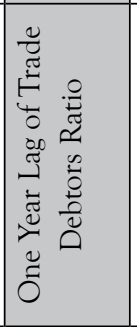 & 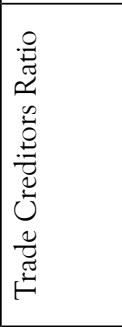 & + & 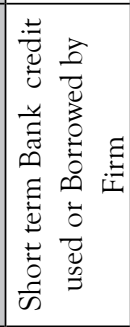 & 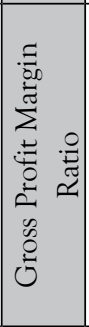 & 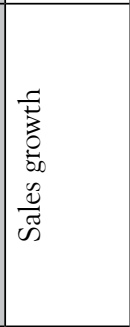 & & 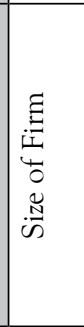 & 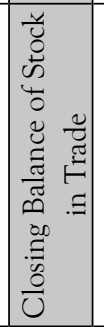 & 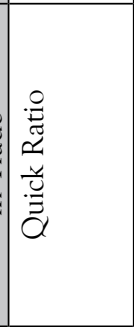 \\
\hline 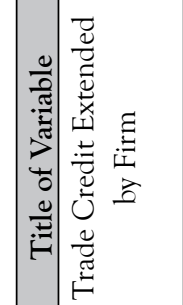 & 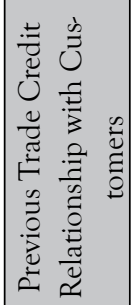 & 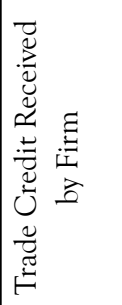 & 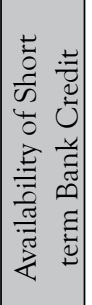 & 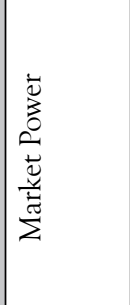 & 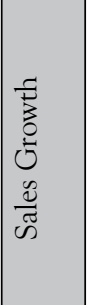 & 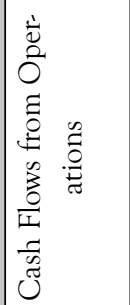 & 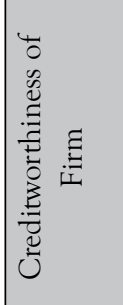 & 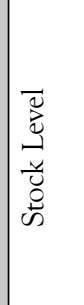 & 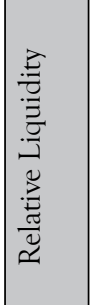 & \\
\hline
\end{tabular}


is a vector of unknown parameters which are to be estimated. $\varepsilon_{\mathrm{it}}$ is the residual term for firm $i$ and time $t$. In order to reach at the targeted level of trade credit, firms make adjustments in the level of trade credit extended in the previous period. The adjustment process of firms is influenced by the speed of adjustment $(\lambda)$. Equation 2 demonstrates the adjustment process followed by firms to adjust the level of trade credit extended by them.

$$
T C E_{i, t}-T C E_{\mathrm{i}, \mathrm{t}-1}=\lambda\left(T C E^{*}{ }_{i t}-T C E_{i, t-1}\right) ; 0 \leq \lambda \geq 1
$$

In equation $2, \mathrm{TCE}^{*}{ }_{\mathrm{it}}$ is the actual trade credit extended by firm $i$ at time $t$. It is measured by the ratio of trade receivables to sales and used as a proxy to describe the trade credit extended or supplied by a firm $i$ during time t. TCE ${ }_{\mathrm{it}}{ }_{\mathrm{t}}$ is the target level for trade credit extended set by firms. $\mathrm{TCE}_{\mathrm{it}-1}$ is the trade credit extended by firm $i$ at time $t-1$.

The expression $\mathrm{TCE}^{*}{ }_{\mathrm{it}}$ is the adjustment that should be made by firms to reach at the targeted level of trade credit. Coefficient $(\lambda)$ is the measure of adjustment speed followed by firms and is inversely related with adjustment cost. The value of Coefficient $(\lambda)$ may vary between 0 and 1 . If $(\lambda)$ is equal to one and $\mathrm{TCE}_{\mathrm{it}}=\mathrm{TCE}_{\mathrm{it}-1}$. It means there is no cost of making adjustments and firms can make instant changes in the level of trade credit extended to reach at the targeted level. On the other hand, if $(\lambda)$ is equal to zero and $\mathrm{TCE}_{\mathrm{it}}=\mathrm{TCE}_{\mathrm{it}-1}$. It implies that there is very high adjustment cost and firms cannot afford it and make no adjustment in the trade credit extended in the previous period. Consequently, the level of trade credit extended in the current period remained same as it was in the previous period. Temporal dependency of trade credit extended by listed manufacturing firms necessitates the use of dynamic panel models to control for dynamics of the process.

Therefore, following dynamic panel data model (Equation 3) is developed by putting equation 1 into equation 2 for investigating the determinants of trade credit extended by manufacturing firms listed in Pakistan.

$$
\begin{aligned}
& T C E_{i, t}=\beta_{0}+\beta_{0} T C E_{i, t-1}+\sum_{j=1}^{N} \beta_{j} X_{j, i t}+\lambda_{i} I D_{i}+\rho_{t} Y D_{t}+\mu_{i t} \\
& \text { Where; } i=1 \ldots \ldots . . N \text { (Firm) and } t=1 \ldots \ldots . . T \text { (Year) }
\end{aligned}
$$

In Equation $3, \beta_{0}$ is constant and is equal to $\lambda \delta_{0} . \beta_{0}$ is the adjustment cost and is equal to $1-\lambda . \mathrm{X}_{\mathrm{j}, \mathrm{it}}$ is a vector of firm level explanatory independent variables and $\beta_{\mathrm{j}}$ is a vector of unknown parameter and is equal to $(\lambda \delta \mathrm{j})$. ID $\mathrm{D}_{\mathrm{i}}$ indicates the industry dummy variable and used to incorporate the effects of unobservable industry specific factors. $\mathrm{YD}_{\mathrm{t}}$ indicates the time dummy variables that are added in the model to incorporate the effects of unobservable variables that change over time but remain 
same for all firms. $\mu_{\mathrm{it}}$ is the random error term and is equal to $\left(\lambda \varepsilon_{\mathrm{it}}\right)$. It explains the effects of unobserved random variables for firm $i$ and time $t$.

$$
T C E_{i, t}=\beta_{0}+\beta_{0} T C E_{i, t-1}+\sum_{j=1}^{N} \beta_{j} X_{j, i t}+\lambda_{i} I D_{i}+\rho_{t} Y D_{t}+\mu_{i t}
$$

Where; $i=1 \ldots \ldots . . N$ (Firm) and $t=1 \ldots \ldots . . T$ (Year)

In Equation $4, \beta_{0}$ is constant and is equal to $\lambda \delta_{0} \cdot \beta_{0}$ is the adjustment cost and is equal to $1-\lambda . X_{\mathrm{j}, \mathrm{it}}$ is a vector of firm level explanatory independent variables and $\beta_{\mathrm{j}}$ is a vector of unknown parameter and is equal to $\left(\lambda \delta_{i}\right)$. ID indicates the industry dummy variable and used to incorporate the effect of unobservable industry specific factors. $\mathrm{YD}_{\mathrm{it}}$ indicates the time dummy variables that are added in the model to incorporate the effects of unobservable variables that change over time but remain same for all firms. $\mu_{\mathrm{it}}$ is the random error term and is equal to $\left(\lambda \varepsilon_{\mathrm{it}}\right)$. It explains the effects of unobserved random variables for firm $i$ and time $t$. Trade credit extended by listed manufacturing firms is likely to be influenced by their financial characteristics which include; trade credit received from their suppliers, short term credit received from banks, their market power, sales growth, cash flows from operations, their size and relative liquidity position etc. Following is the detailed specification for the investigation of determinants of trade credit extended by listed manufacturing firms.

$$
\begin{aligned}
T C E_{i, t} & =\beta_{0}+\beta_{0} T C E_{i, t-1}+\beta_{1} T C R_{i t}+\beta_{2} S B C_{i t}+\beta_{3} G P_{i t}+\beta_{4} S G_{i t}+\beta_{5} C F O_{i t}+\beta_{6} S I Z_{i t} \\
& +\beta_{7} S T_{i t}+\beta_{8} R L I Q_{i t}+\lambda_{i} I D_{i}+\rho_{t} Y D_{t}+\mu_{i t}
\end{aligned}
$$

In Equation 5, $\mathrm{X}_{\mathrm{it}}$ is replaced by time variant firm specific determinants of trade credit extended by firms. Title of variables used equation 5 , their proxies, measurement and symbols are described in the Table 1 .

\subsection{Estimation choice}

Panel data has the ability to deal with both cross-sectional and time-series variation in the data. This double dimension is helpful in better understanding of individual behavior. Second, it has ability to incorporate the information about inter temporal dynamics and individual specific effects that is helpful in controlling the effect of missing or unobserved variables. But the dynamic panel data structure and simultaneity bias give rise to endoginiety that is a serious concern in corporate finance. Some sort of causality is likely to exist between trade credit extended by firms and its firm specific determinants. For instance, according to credit redistribution hypothesis firms extending more trade credit to their customers are likely to receive more trade credit and short term bank credit.

Commercial motive of trade credit emphasizes that firm's use liberal trade credit policy to increase stock turnover. Firms selling on credit have incentive to earn higher 
gross profit margin. Price discrimination motive emphasize that firms charge higher gross profit margin for credit sales. Liberal trade credit policy reduces the cash flows generated from operations. The presence of causality between trade credit extended and its determinants give rise to simultaneity bias. Moreover, these endogenous variables are serially correlated with the current and even with past residuals term and creates biased and inconsistent estimates. Unobserved heterogeneity among firms and simultaneity bias give rise to endogeneity. This renders the estimates to be inconsistent and biased.

Moreover, due to data structure used in this study (smaller size of $T=11$, relative to a larger size of $N=377$ ); the inconsistency becomes more severe. First differenced-GMM has poor finite sample properties, and it is downwards biased, especially when $T$ is small. Arellano and Bover (1995) as well as Blundell and Bond (1998) proposed the use of system GMM estimator (thereafter called BB estimator) to control the endogeneity problem particularly when panel data set has finite $T$ but infinite $N$. There are two versions of system GMM estimator i.e. one-step system-GMM and two step system GMM developed by Blundell and Bond (1998). In case of heteroscedasticity, estimated coefficients produced by two step estimator are considered more efficient. From among the diagnostic test for dynamic panel, Hansen test of over identifying restrictions is used to verify the validity of instruments used in system GMM estimator. Where null hypothesis is that, residual term and instruments are uncorrelated. Existence of serial correlation of error term can affect the validity of some instruments. It is detected by using test proposed by Arellano and Bond (1991) for identifying existence of serial correlation of disturbance term of first order at level and second order serial correlation at difference. Null hypothesis for this test is that there is no serial correlation of order 1 and 2 .

\section{Data Analysis and Discussion of Results}

For achieving the objective of the study, analysis of balanced panel data set is performed. Results of analysis and their interpretation are presented at two levels in this section.

\subsection{Descriptive analysis}

Descriptive statistics such as mean, standard deviation, minimum and maximum values are computed and reported in Table 2. Average trade credit extended by firms over the period of study is $10.73 \%$ of sales with standard deviation $11.28 \%$. Standard deviation shows significant variation in trade credit extended across firms and over the period of study. Maximum trade credit extended by firms is $98.65 \%$ and minimum trade credit extended by firms is $1.31 \%$. Average trade credit received by 
firms is $12.71 \%$ of sales with standard deviation $14.38 \%$. Standard deviation shows trade credit received by firms from their suppliers varies significantly across firms and over the period of study. Maximum trade credit received by firms is $79.86 \%$ of sales while minimum trade credit received by listed manufacturing firms is $2.12 \%$. Average short term bank credit received by firms is $27.14 \%$ of sales with standard deviation $34.40 \%$. It shows all firms have access to short term bank credit but it substantially varies across firms and over the period of study. Mean value for the measure of market power of firms is $11.46 \%$ with standard deviation $13.62 \%$. It shows that some firms have very strong market power while others have very weak market power. On average firms have grown up by $15.47 \%$ and large standard deviation indicates that firms' growth rate is very sensitive and significantly varies around the mean.

Table 2: Descriptive Analysis

\begin{tabular}{|c|c|c|c|c|}
\hline Name of Variable & Mean Value & Standard Deviation & Mini. Value & Maxi. Value \\
\hline TCE & 0.1073 & .1128 & 0.0103 & 0.9865 \\
\hline TCR & 0.1271 & 0.1438 & 0.0212 & 0.7986 \\
\hline SBC & 0.2714 & 0.3440 & 0.0000 & 3.9511 \\
\hline MP & 0.1146 & 0.1362 & -0.3727 & 0.606 \\
\hline SG & 0.1547 & 0.3214 & -0.5737 & 0.9133 \\
\hline CFO & 0.0575 & 0.1581 & -0.6332 & 0.6132 \\
\hline SIZ in Thousands Rs. & 8889201 & 28756432 & 1263 & 410486745 \\
\hline ST & 0.1790 & 0.1196 & 0.0005 & 1.5937 \\
\hline RLIQ & 0.4916 & 0.5771 & 0.02 & 2.82 \\
\hline
\end{tabular}

No. of Firms $=327$ Years $=11$, No. of firm year Observations: 3597

On average, firms generated cash inflows from operations during the period of study. Mean value of relative liquidity is $49.16 \%$ which shows that on average firms have liquid assets equal to $49.16 \%$ of their current liabilities. It means overall relative liquidity position of sampled firms remained satisfactory during the period of study. Descriptive analysis revealed the existence of extreme observations. Similar to Desai et al. (2016), this study reduces the effect of outliers by winsorizing each firm specific variable at the 5 percent from both lower and upper tails of distribution.

\subsection{Panel unit root test}

Harris-Tzavalis panel unit root test was conducted to check the presence of unit root in panels. Results of unit root test are reported in Table 3 which is provided in appendix A. 
Results of Harris-Tzavalis panel unit root test show that all variables to be included in the models are integrated of order zero and imply the absence of unit roots in the panel data. Thus, these variables at level will not produce spurious and wrong predictions when regressed at level.

\subsection{Empirical analysis}

To investigate the determinants of trade credit supplied and received by firms, correlation and regression analysis are performed.

\subsubsection{Correlation analysis}

In order to measure the degree of association between variables, Pearson Correlation (pairwise) test is applied on the data set consists of firms' financial characteristics. Results reported in Table 4 show that coefficients of correlation between trade credit extended and independent variables are significant at the 0.05 level. High degree of association is observed between trade credit extended in current period and trade credit extended in the previous period. It implies the existence of temporal dependency and consistency in the trade credit policy. Findings also show that trade credit extended is positively related with trade credit received and short term bank credit. It means firms receiving more credit from suppliers and banks extend more trade credit to their customers. Coefficient of correlation between independent variables is less than thresh hold 0.60 except coefficient of correlation between trade credit used by firms and their size. In order to test severity of multicolinearity problem among independent variables, Variance inflation factor (VIF) test is applied after running regression model and its results are reported in Table 4.

VIFs for all firm specific independent variables are less than 4 which shows that use of all independent variables as a set in one regression model, does not create a serious concern of multicolinearity issue. Thus, we used all independent variables as a set in one regression model.

\subsubsection{Results of regression analysis and discussion}

In order to investigate the firm specific determinants of trade credit extended by firms, Equation 5 is estimated by applying pooled OLS, fixed effect and system GMM with one step and two step on the balanced panel data set of 327 manufacturing firms listed in PSX for the period of 2005-2015. Results are reported in Table 5.

Statistics for static panel specification tests (F-test, Breusch-Pagan LM Test and HausmanTest) reported in Table 5, shows existence of fixed effect and preference of fixed effect estimators over random effect estimators. But in case of endogeneity, 


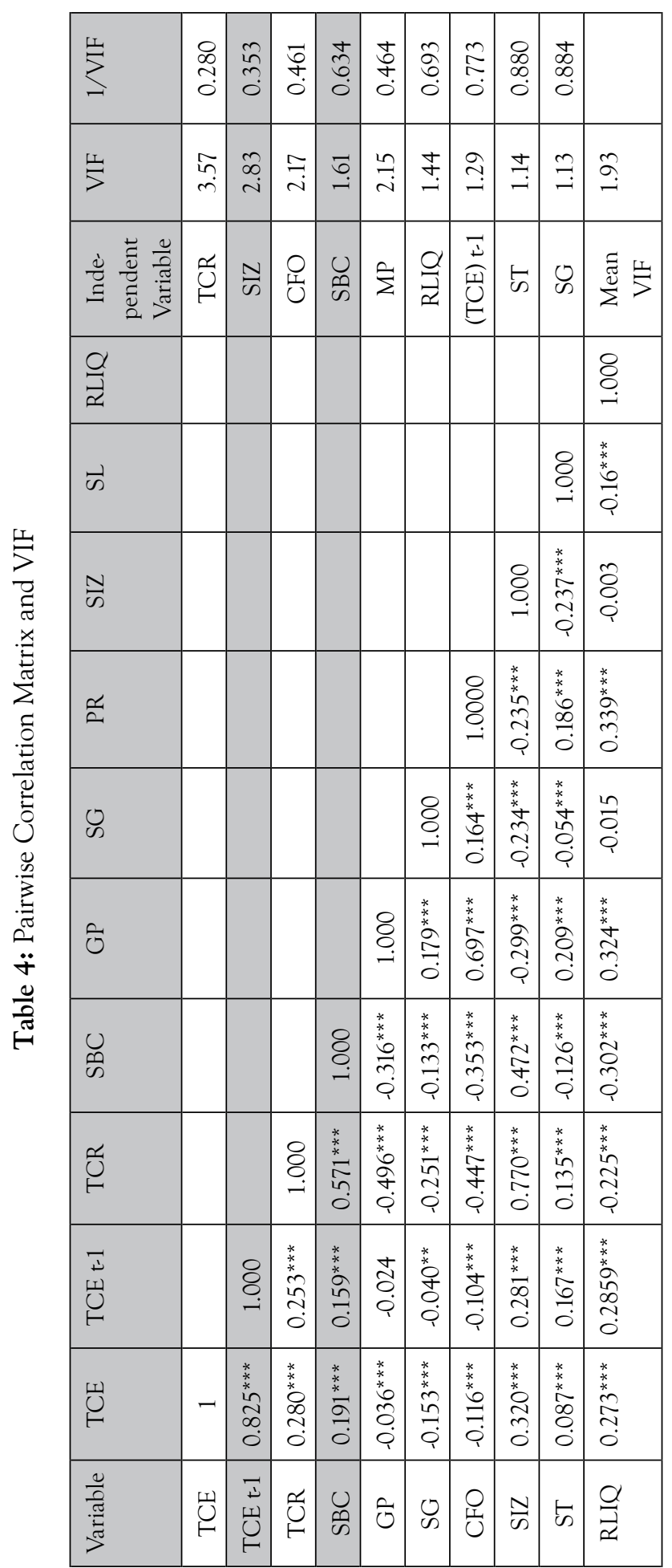

我

莡

気

节

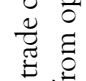

咅点

U는

चु

氙

节苛

t5

苛

บิ

$\therefore 0$

$\vec{\nabla}$

$\stackrel{2}{\approx}$

茪

氖

矛范

* 0

in

己.

范疍

苋 है

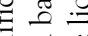

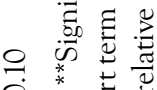

$0^{*} 0^{\circ}$

* 0 क

药寻记

จे की

*

$\ddot{\bar{O}}$ 艺

它

के

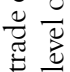


estimates of coefficients produced by Pooled OLS, fixed effect and random effect estimators are inconsistent and biased. System GMM estimators are reliable one regardless of the level of endogeneity or dependent variable persistence and should be the best choice under these conditions, particularly if the lag coefficient is of interest. For one step and two step system-GMM estimations presented in column 6 and 7 of Table 5, trade credit received from suppliers, short term credit received from banks, sales growth, operating cash flows, relative liquidity position and stock level are used as endogenous variables while year dummies and industry dummies are added in system GMM models as exogenous regressors and also serve as instruments. System GMM estimators can control serial correlation of regressors by using a system of two equations, one at first difference and other at level.

Total 196 instruments are used in both one step and two step system GMM estimation. Instruments used in first difference equation and level equation are: first to third lagged values of trade credit received, short term bank credit received, gross profit, sales growth, cash flows from operations, stock level and relative liquidity position; first lagged of creditworthiness, depth of financial institutions, depth of financial market, industrial production growth, lending rate and credit information sharing; and year dummies at level for year 2005 through 2015. GMM type instruments include second lag to fourth lag of all endogenous independent variables (separate instruments for each period unless collapsed).

Diagnostics test for system GMM estimation are reported in Table 5. Wald test of joint significance shows that all estimated coefficients are jointly significant at the 0.01 level. Test of serial correlation AR (1) show the presence of first order serial correlation while AR (2) test indicates no evidence of second order serial correlation. Absence of serial correlation at second order is a sufficient evidence for the validity of instruments and correct specification of both versions of system GMM model. Furthermore, Hansen J-statistic shows strong evidence of the validity of instruments used in both one step and two step system GMM that is consistent with null hypothesis of validity of over identifying restrictions. In the presence of heteroskedastic residuals, two step system GMM estimators with robust option produces more efficient estimates for coefficients than one step system GMM estimators (Kabango, 2009).

Results reported in Table 5 shows that coefficient of first lag of trade credit extended (dependent variable), produced by two step system GMM is 0.6746 which is found lying in between the coefficients produced by Pooled OLS and Fixed Effect (within) estimators. It implies that the coefficient produced by two step system GMM is likely to be less biased. Results of both one-step and two-step System GMM are reported in the table 5 but due to superiority of two step system GMM estimation only its results are discussed 
Table 5: Firm Specific Determinants of Trades Credit Extended by Firms (Dependent Variable: TCE)

\begin{tabular}{|c|c|c|c|c|c|c|c|}
\hline 1 & 2 & 3 & 4 & 5 & 6 & 7 & 8 \\
\hline \multirow{2}{*}{$\begin{array}{c}\text { Inde- } \\
\text { pendent } \\
\text { Variables }\end{array}$} & \multirow{2}{*}{$\begin{array}{l}\text { Exp. } \\
\text { Sign }\end{array}$} & \multirow{2}{*}{$\begin{array}{l}\text { Obs. } \\
\text { Sign }\end{array}$} & \multirow{2}{*}{$\begin{array}{c}\text { Pooled } \\
\text { OLS }\end{array}$} & \multirow{2}{*}{$\begin{array}{l}\text { Fixed } \\
\text { Effect }\end{array}$} & \multicolumn{2}{|c|}{ System GMM } & \multirow{2}{*}{$\begin{array}{c}\text { Alternative } \\
\text { Hypothesi } \\
\mathrm{Ha}\end{array}$} \\
\hline & & & & & One Step & Two Step & \\
\hline \multirow[t]{2}{*}{ TCE t-1 } & + & + & $0.7845^{* * *}$ & $0.3787^{* * *}$ & $0.6600^{* * *}$ & $0.6746^{* * *}$ & Accepted \\
\hline & & & $(0.0225)$ & $(0.0537)$ & $(0.0450)$ & $(0.0440)$ & \\
\hline \multirow[t]{2}{*}{ TCR } & + & + & $0.0381^{*}$ & 0.0468 & $0.1603^{* * *}$ & $0.1455^{* * *}$ & Accepted \\
\hline & & & $(0.0233$ & $(0.0351)$ & $(0.0418)$ & $(0.0404)$ & \\
\hline \multirow[t]{2}{*}{$\mathrm{SBC}$} & + & + & $0.0127^{*}$ & 0.0090 & $0.0191^{*}$ & $0.0190^{*}$ & Accepted \\
\hline & & & $(0.0077)$ & $(0.0121)$ & $(0.0108)$ & $(0.0098)$ & \\
\hline \multirow[t]{2}{*}{ GP } & $+/-$ & + & $0.0319^{* *}$ & $0.0585^{* *}$ & $0.0456^{*}$ & 0.0321 & $\begin{array}{c}\text { Not accept- } \\
\text { ed }\end{array}$ \\
\hline & & & $(0.0157)$ & $(0.0288)$ & $(0.0239)$ & $(0.0215)$ & \\
\hline \multirow[t]{2}{*}{ SG } & $+/$. & - & $-0.0366^{* * *}$ & $-0.0195^{* * *}$ & $-0.0356^{* * *}$ & $-0.0335^{* * *}$ & Accepted \\
\hline & & & $(0.0059)$ & $(0.0058)$ & $(0.0079)$ & $(0.0072)$ & \\
\hline \multirow[t]{2}{*}{$\mathrm{CFO}$} & $+/-$ & - & -0.0170 & $-0.0422^{* *}$ & -0.0140 & -0.0178 & $\begin{array}{c}\text { Not accept- } \\
\text { ed }\end{array}$ \\
\hline & & & $(0.0140)$ & $(0.0179)$ & $(0.0222)$ & $(0.0203)$ & \\
\hline \multirow[t]{2}{*}{ SIZ } & $+/$. & - & 0.0022 & $0.0146^{* * *}$ & $-0.0115^{* *}$ & $-0.0104^{* *}$ & Accepted \\
\hline & & & $(0.0023)$ & $(0.0046)$ & $(0.0048)$ & $(0.0043)$ & \\
\hline \multirow[t]{2}{*}{ ST } & $-1+$ & + & $0.0503^{* * *}$ & $0.0660^{* *}$ & $0.0793^{* *}$ & $0.0670^{* *}$ & Accepted \\
\hline & & & $(0.0167)$ & $(0.0288)$ & $(0.0357)$ & $(0.0323)$ & \\
\hline \multirow[t]{2}{*}{ RLIQ } & + & + & $0.0182^{* * *}$ & $0.0214^{* * *}$ & $0.0336^{* * *}$ & $0.0316^{* * *}$ & Accepted \\
\hline & & & $(0.0033)$ & $(0.0058)$ & $(0.0064)$ & $(0.0071)$ & \\
\hline \multirow[t]{2}{*}{ Constant } & & -0.0034 & $0.0208^{* *}$ & -0.0027 & 0.0042 & & \\
\hline & & $(0.0052)$ & $(0.0084)$ & $(0.0070)$ & $(0.0072)$ & & \\
\hline $\begin{array}{c}\text { Adj.R2 / } \\
\text { Overall R2 }\end{array}$ & 0.7145 & 0.6496 & & & & & \\
\hline R2 Within & & 0.3035 & & & & & \\
\hline $\begin{array}{l}\text { R2 Be- } \\
\text { tween }\end{array}$ & & 0.8366 & & & & & \\
\hline $\begin{array}{c}\text { Wald } \\
\text { chi2(9) } \\
\text { Prob > chi2 }\end{array}$ & & $\begin{array}{c}6505.55 \\
(0.000)\end{array}$ & $\begin{array}{l}1026.31 \\
(0.000)\end{array}$ & $\begin{array}{l}993.91 \\
(0.000)\end{array}$ & & & \\
\hline
\end{tabular}




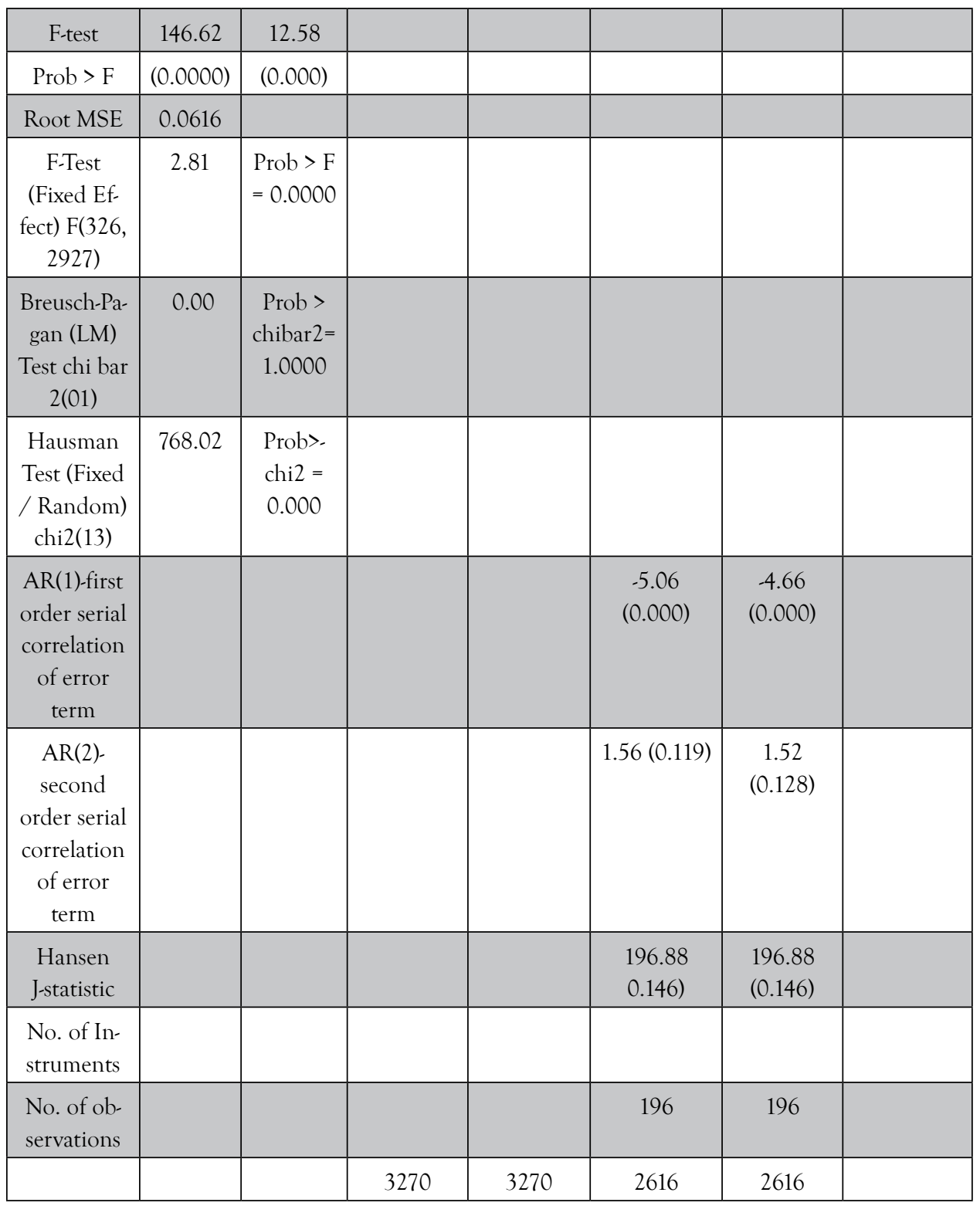

${ }^{*}$ Significant at level $10 \%,{ }^{* *}$ Significant at level 5\%, ${ }^{* *}$ Significant at level $1 \%$.

i) TCE, trade credit extended is a depended variable; ii) Firms specific independent variables used in all models, include: TCEt-1, trade credit extended in year $\mathrm{t}-1$. TCR, trade credit received from suppliers; SBC, short term bank credit received; GP, gross profit ratio used as proxy for market power of a firm, SG, sales growth rate; CFO, cash flows from operations; SIZ, size of a firm and used as proxy of creditworthiness; ST, level of stock in trade; RLIQ, relative liquidity position.. iii) Heteroskedasticity robust standard error are reported in parenthesis. (iv) The annual time coverage for all the models is 2005 to 2015. 
i) TCE, trade credit extended is a depended variable; ii) Firms specific independent variables used in all models, include: TCE $E_{t-1,}$ trade credit extended in year $t-1$. TCR, trade credit received from suppliers; SBC, short term bank credit received; GP, gross profit ratio used as proxy for market power of a firm, SG, sales growth rate; CFO, cash flows from operations; SIZ, size of a firm and used as proxy of creditworthiness; ST, level of stock in trade; RLIQ, relative liquidity position.. iii) Heteroskedasticity robust standard error are reported in parenthesis. (iv) The annual time coverage for all the models is 2005 to 2015.

Positive and below unity coefficient for (TCE) ${ }_{\mathrm{t}-1}$ of trade credit extended implies that Pakistani listed manufacturing firms have target (optimal) ratio for trade credit extended to their customers and it is persistent over time. The findings support the trade credit relationship theory i.e. firms continue to extend credit to their customers on basis of their previous credit relationship. The speed at which listed manufacturing firms adjust their trade credit extended is $(1-0.6746=0.32)$. Consistent with the findings of Kwenda and Holden (2014), manufacturing firms listed in Pakistan have to face higher cost for making adjustments in the level of trade credit extended. Thus, it is concluded that firms' policy for extension of trade credit is dynamic in nature and firms partially make adjustments in it at a relatively slow speed due to high adjustment cost.

Trade credit received by firms is predicted to be positively related with trade credit extended to their customers. Findings are consistent with trade credit redistribution hypothesis i.e. firms receiving more trade credit from their suppliers are expected to extend more trade credit to their customers (Yang, 2011). Findings also show that firms follow maturity matching principle and use trade payables (current liability) to finance their trade receivables. Results are also found consistent with the findings of previous studies conducted by Ferrando and Mulier, (2013), Al-Dohaiman (2013) and Murfin and Njoroge (2015). Thus findings of this study are consistent with liquidity and financing theories of trade credit.

Short term bank credit used by firms is found positively related to trade credit extended by firms to their customers. Results are in accordance with the credit redistribution hypothesis of trade credit i.e. firms with better access to bank credit redistribute part of it to their credit rationed customers by providing them trade credit (Bougheas et al.,2009). Similar results were reported by previous studies (see for example Mateut, et al., 2011; Yang, 2011). Thus, findings of the study confirm the financing and liquidity theories of trade credit.

Direction of relationship between gross profit margin and trade credit extended is supported by price discrimination motive of trade credit. Moreover, the results are consistent with the findings of Niskanen, and Niskanen (2006). Sales growth and trade 
credit extended are found negatively related with each other. It implies that firms with positive growth need funds to support their own operating activities and provide less credit to their customers. The results are similar to the findings of previous studies (see for example Delannay \& Weill, 2004; Deloof \& Rocca, 2012). The results show that firms are not pursuing commercial motives through trade credit.

Negative coefficient for cash flows from operations is according to theory but not significant at the 0.05 level. Results shows that firms facing decrease in cash flows from operations might be due to delayed payment allowed to customers. The results are according to financial distress theory. Size of the firms is used as a proxy for their creditworthiness and is predicted to be negatively related with trade credit extended which is consistent with the findings of Grave (2011). The results are in accordance with market power theory i.e. larger and credit worthy firms have strong bargaining power and negotiate credit terms in their own favor.

Contrary to Bougheas et al. (2009) and Vaidya (2011), the level of stocks held by firms is predicted to have a significant and positive effect on trade credit extended by firms. The findings of this study are consistent with the results reported by Deloof and Rocca (2012). These studies established that trade credit extended and stock in trade, both are current assets are complements of each other. Relative liquidity position of firms is revealed to be positively related with trade credit extended by them. It implies that firms with lower liquidity risk provide more credit to their customers by allowing delayed payments. Thus, results support the liquidity motive of trade credit and are consistent to the findings of Vaidya (2011). The findings of the study support the liquidity theory of trade credit.

\section{Conclusion and Recommendations}

This study investigates the determinants of trade credit extended by manufacturing firms listed in PSX. For this purpose, data about financial characteristics of 327 listed manufacturing firms for the period from 2005 to 2015 are analyzed by using dynamic panel model. System GMM (with one-step and two-step) is applied to control the endogeneity and short panel bias. Findings of the study establish that trade credit extended by firms is dynamic in nature. Due to larger cost of making adjustments, firms have relatively stable trade credit policy. Positive relationship of trade credit extended with credit received from suppliers and banks, confirm the credit redistribution behavior of listed manufacturing firms in Pakistan. In addition to credit received from suppliers and banks, some financial characteristics of listed manufacturing firms are also found to have significant impact on the trade credit extended by them to their customers. From among the financial characteristics of firms; sales growth rate, size of firms, stock level and relative liquidity position are found having significant effect 
on the trade credit extended by them to their customers. It means trade credit policy of firms is sensitive to changes in their financial characteristics.

Findings of this study have significant implication for policy makers and academics. For instance, trade credit policies of firms are dynamic, which implies that managers have the opportunity to make adjustments in their trade credit policies over the time for attaining the optimal level of trade credit. While making adjustments in the trade credit policy, managers should consider their experience about past trade credit relationship with their customers and suppliers. Further, due to high cost of making adjustments, it is not feasible for the managers to make abrupt adjustments in trade credit policy of their firms. They should make tradeoff between the cost of making adjustments and cost of staying away from equilibrium. In addition to past trade credit relationship, manager should match trade credit extended with trade credit used in order to avoid liquidity problem. Furthermore, while making changes in trade credit policy managers are advised to consider their growth needs, cash flows generated from operations, unsold stock, creditworthiness and their market power.

However, the findings of this study should be used with care as this study focused on only manufacturing firms listed in PSX. Supply of trade credit by listed manufacturing firms is likely to be in response to demand for trade credit from their customers which in turn depends on the characteristics of their customers. Due to numerous customers and non-availability of their data make it difficult to include their characteristics in this study. Future study may consider the characteristic of listed manufacturing firms as well as their customers. In addition to firm specific characteristics, trade credit supplied by firms is also likely to be influenced by the characteristics of financial system. There is need to study the effect of financial development on the credit redistribution behavior of firms.

\section{References}

Akinlo, O. O. (2012). Effect of working capital on profitability of selected quoted firms in Nigeria. Global Business Review, 13(3), 367-381.

Al Dohaiman, M. S. (2013). Explaining the determinants of trade credit: An empirical study in the case of Saudi Arabian's unlisted firms. Research Journal of Finance and Accounting, 4(17), 204-212.

Arellano, M., \& Bond, S. (1991). Some tests of specification for panel data: Monte Carlo evidence and an application to employment equations. The Review of Economic Studies, 58(2), 277-297.

Arellano, M., \& Bover, O. (1995). Another look at the instrumental variable estimation of error-components models. Journal of Econometrics, 68(1), 29-51.

Bastos, R. R. (2010). A trade credit explanation based on the agency theory, legal factors and credit contagion. 
Doctoral Dissertation, University of De Salamanca.

Biais, B., \& Gollier, C. (1997). Trade credit and credit rationing. Review of Financial Studies, 10(4), 903-937.

Blasio, G. D. (2005). Does trade credit substitute bank credit? Evidence from firm-level data. Economic Notes, 34(1), 85-112.

Blundell, R., \& Bond, S. (1998). Initial conditions and moment restrictions in dynamic panel data models. Journal of Econometrics, 87(1), 115-143.

Bond, S. R. (2002). Dynamic panel data models: a guide to micro data methods and practice. Portuguese Economic Journal, 1(2), 141-162.

Bougheas, S., Mateut, S., \& Mizen, P. (2009). Corporate trade credit and inventories: New evidence of a trade-off from accounts payable and receivable. Journal of Banking $\mathcal{E}$ Finance, 33(2), 300-307.

Brennan, M. J., Maksimovics, V., \& Zechner, J. (1988). Vendor financing. The Journal of Finance, 43(5), $1127-1141$.

Brick, I. E., \& Fung, W. K. (1984). Taxes and the theory of trade debt. The Journal of Finance, 39(4), 1169-1176.

Burkart, M., \& Ellingsen, T. (2004). In-kind finance: A theory of trade credit. The American Economic Review, 94(3), 569-590.

Chou, J. H., Yang, M. C. \& Line, T. T. (2011). An empirical analysis of the effect of credit rating on trade credit. Paper presented at the International conference on Financial Management and Economics IPEDR.11, 278-283 (IACSIT Press, Singapore.

Coulibaly, B., Sapriza, H., \& Zlate, A. (2013). Financial frictions, trade credit, and the 2008-09 global financial crisis. International Review of Economics E Finance, 26, 25-38.

Delannay, A. F., \& Weill, L. (2004). The determinants of trade credit in transition countries. Economics of Planning, 37(3-4), 173-193.

Deloof, M., \& La Rocca, M. (2012). Local financial development and trade credit. University of Strasbourg Working paper.

Deloof, M., \& Van Overfelt, W. (2011). Trade credit and bank relationships: Evidence from pre-World War Belgium. Applied Economics, 43(13), 1647-1655.

Desai, M. A., Foley, C. F., \& Hines Jr, J. R. (2016). Trade credit and taxes. Review of Economics and Statistics, 98(1), 132-139.

Diamond, D. W. (1991). Monitoring and reputation: The choice between bank loans and directly placed debt. Journal of political Economy, 99(4), 689-721.

Emery, G. W. (1987). An optimal financial response to variable demand. Journal of Financial and Quantitative Analysis, 22(02), 209-225. 
Emery, G. W. (1984). A pure financial explanation for trade credit. Journal of financial and quantitative analysis, 19(3), 271-285.

Fazel, F. (1997). A comparative analysis of inventory costs of JIT and EOQ purchasing. International Journal of Physical Distribution $\mathcal{E}$ Logistics Management, 27(8), 496-504.

Ferrando, A., \& Mulier, K. (2013). Do firms use the trade credit channel to manage growth? Journal of Banking $\mathcal{E}$ Finance, 37(8), 3035-3046.

Flannery, M. J., \& Hankins, K. W. (2013). Estimating dynamic panel models in corporate finance. Journal of Corporate Finance, 19, 1-19.

Ge, Y., \& Qiu, J. (2007). Financial development, bank discrimination and trade credit. Journal of Banking E Finance, 31(2), 513-530.

Gibilaro, L., \& Mattarocci, G. (2011). Interaction between trade credit and debt: Evidence from the Italian market. International Business $\mathcal{E}$ Economics Research Journal (IBER), 10(3), 103-112.

Garcia-Teruel, P. J., \& Martinez-Solano, P. (2010a). Determinants of trade credit: A comparative study of European SMEs. International Small Business Journal, 28(3), 215-233.

Garcia-Teruel, P. J., \& Martinez-Solano, P. (2010b). A dynamic perspective on the determinants of accounts payable. Review of Quantitative Finance and Accounting, 34 (4), 439-457.

Grave, T. (2011). Trade credit as a shock absorber? The effects of the financial crisis on the use of trade credit by Dutch manufacturing firms. Master's thesis, University of Twente.

Guy, O. R., \& Mazra, M. (2012). The determinants of trade credit demand: An empirical study from Cameroonian firms. International Journal of Business and Management, 7(17), 43-59.

Huyghebaert, N. (2006). On the Determinants and dynamics of trade credit use: Empirical evidence from business Startlups. Journal of Business Finance $\mathcal{E}$ Accounting, 33(1-2), 305-328

Jain, N. (2001). Monitoring costs and trade credit. The Quarterly Review of Economics and Finance, 41(1), 89-110.

Jensen, M. C., \& Meckling, W. H. (1976). Theory of the firm: Managerial behavior, agency costs and ownership structure. Journal of Financial Economics, 3(4), 305-360.

Kabango, G. P. (2009). Financial liberalization and industry structure nexus: an investigation using dynamic heterogeneous panels from Malawian data. Doctoral dissertation, University of Glasgow.

Khan, M. A., Tagar, G. A., \& Bhutto N. A. (2012). Determinants of accounts receivable and accounts payable: A case of Pakistani textile sector. Interdisciplinary Journal of contemporary Research in Business, 3(9), 240-251.

Kiyotaki, N., \& Moore, J. (1997). Credit cycles. Journal of Political Economy, 105(2), 211-248.

Kwenda, F., \& Holden, M. (2014). Trade credit in corporate financing in South Africa: Evidence from 
a dynamic panel data analysis. Investment Management and Financial Innovations, 11(4), 268-278.

Mateut, S., Bougheas, S., \& Mizen, P. (2006). Trade credit, bank lending and monetary policy transmission. European Economic Review, 50(3), 603-629.

Mateut, S., Mizen, P., \& Ziane, Y. (2011). Supplier-customer relationships and the interactions between inventories and trade credit. NUBS Research Paper Series, 2.

McMillan, J., \& Woodruff, C. (2002). The central role of entrepreneurs in transition economies. The Journal of Economic Perspectives, 16(3), 153-170.

Meltzer, A. H. (1960). Mercantile credit, monetary policy, and size of firms. The Review of Economics and Statistics, 429-437.

Mian, S. L., \& Smith, C. W. (1992). Accounts receivable management policy: Theory and evidence. The Journal of Finance, 47(1), 169-200.

Murfin, J., \& Njoroge, K. (2015). The implicit costs of trade credit borrowing by large firms. Review of Financial Studies, 28(1), 112-145.

Nilsen, J. (2002). Trade credit and the bank lending channel. Journal of Money, Credit, and Banking, 34, $226-253$.

Niskanen, J., \& Niskanen, M. (2006). The Determinants of corporate trade credit policies in a bank-dominated financial environment: The case of Finnish small firms. European Financial Management, 12(1), 81-102.

Oliveira Marques, J. M. (2010). The Days to pay accounts payable determinants-financing, pricing motives and financial substitution effect: A panel data GMM estimation from European Western Countries. Retrieved from: https://papers.ssrn.com/sol3/papers.cfm?abstract_id=1805245

Omiccioli, M. (2005). Trade credit as collateral (No. 553). Bank of Italy, Economic Research and International Relations Area.

Petersen, M. A., \& Rajan, R. G. (1994). The benefits of lending relationships: Evidence from small business data. The Journal of Finance, 49(1), 3-37.

Petersen, M. A., \& Rajan, R. G. (1997). Trade credit: theories and evidence. Review of Financial Studies, 10(3), 661-691.

Rajan, R. G., \& Zingales, L. (1995). What do we know about capital structure? Some evidence from international data. The Journal of Finance, 50(5), 1421-1460.

Roberts, M. R., \& Whited, T. M. (2013). Endogeneity in empirical corporate finance. Handbook of the Economics of Finance, 2, 493-572.

Schwartz, R.A. (1974). An economic model of trade credit. Journal of Financial and Quantitative Analysis 9, 643-657. 
Smith, J.K. (1987). Trade credit and informational asymmetry. Journal of Finance, 42(4), 863-872.

Tsuruta, D. (2013). Customer relationships and the provision of trade credit during a recession. Applied Financial Economics, 23(12), 1017-1031.

Vaidya, R. R. (2011). The determinants of trade credit: Evidence from Indian manufacturing firms. Modern Economy, 2(5), 707-716.

Wilson, N., \& Summers, B. (2002). Trade credit terms offered by small firms: Survey evidence and empirical analysis. Journal of Business Finance $\mathcal{F}$ Accounting, 29(3-4), 317-351.

Yang, X. (2011). Trade credit versus bank credit: Evidence from corporate inventory financing. The Quarterly Review of Economics and Finance, 51(4), 419-434.

Zhang, R. (2011). The role of information sharing in trade credit distribution: evidence from Thailand. Asian-Pacific Economic Literature, 25(1), 133-149.

\section{Appendix A}

Table 3. Harris-Tzavalis Panel Unit Root Test Results

\begin{tabular}{|c|c|c|c|}
\hline Variables & Rho Statistics & $\mathrm{Z}$ & Order of Integration \\
\hline TCE & 0.4477 & $-15.1221^{* * *}$ & 0 \\
\hline TCR & 0.4606 & $-14.3495^{* * *}$ & 0 \\
\hline SBC & 0.5813 & $-7.1126^{* * *}$ & 0 \\
\hline MP & 0.4340 & $-15.9405^{* * *}$ & 0 \\
\hline SG & -0.0341 & $-43.9959^{* * *}$ & 0 \\
\hline CFO & 0.2949 & $-24.2798^{* * *}$ & 0 \\
\hline SIZ & 0.3851 & $-18.8718^{* * *}$ & 0 \\
\hline ST & 0.4566 & $-14.5871^{* * *}$ & 0 \\
\hline RLIQ & 0.3248 & $-22.4839^{* * *}$ & \\
\hline
\end{tabular}

${ }^{* * *} \mathrm{p}<0.01 ;{ }^{* *} \mathrm{p}<0.05 ;{ }^{*} \mathrm{p}<0.10$

Source: Own calculations using a balanced panel data set of 327 firms for the period 2005-2015. *Significant at the $10 \%$ level, ${ }^{* *}$ Significant at the $5 \%$ level, ${ }^{* * *}$ Significant at the $1 \%$ level. ) TCE, trade credit extended is a depended variable; ii) Firms specific independent variables used in all models, include: TCEt-1, trade credit extended in year $\mathrm{t}-1$. TCR, trade credit received from suppliers; SBC, short term bank credit received; GP, gross profit ratio used as proxy for market power of a firm, SG, sales growth rate; CFO, cash flows from operations; SIZ, size of a firm and used as proxy of creditworthiness; ST, level of stock in trade; RLIQ, relative liquidity position. 